\title{
Differences in Attitudes towards Female Managers: Lessons from Technology Start-Up Companies in Jakarta, Indonesia
}

\author{
Daniya $^{1 *}$, Risa Bhinekawati ${ }^{2}$ \\ ${ }^{1,2}$ Sekolah Tinggi Manajemen Ipmi, DKI Jakarta 12750, Indonesia
}

ART ICLE INFO

\begin{abstract}
A B S T RA C T
Despite the perceptions that such technology start-up companies are known as a modern working environment that embraces diversity, the data shows that the number of women in the industry, especially in a senior position, is still lower than men. Naturally, men have a high sense of competitiveness and feel more superior to become managers compared to women; while women sometimes practice self-stereotyping and think they are not capable enough for being a leader. This study aims to investigate differences in the attitude of men and women towards female managers in technology start-up companies. This research applies mixed methods, using "Women as Managers Scale (WAMS)" as indicators in the quantitative data collected from 60 male and 60 female that work in technology startup companies in Jakarta. WAMS was also used as the basis for interview questions with three men and three women are being interviewed for the qualitative approach. The study finds differences in the attitude between men and women towards female manager in the technology startup companies in Jakarta, Indonesia. Compared to men, women respondents have more positive attitudes in terms female managers' ability, acceptance, physical constraints and leadership. On the contrary, men respondents view that physical constraints like menstruation and maternity leave would affect female managers' performance. Theoretically, this study contributes to the knowledge of gender diversity at work in the context of technology start-up companies in Indonesia. Practically, managers can use lessons from this study to develop a more gender balanced strategy for the companies.
\end{abstract}

Article History:

Received : 18-08-2019

Revised : 02-10-2019

Accepted : 20-10-2019

Published : 28-10-2019

Keywords:

Female Manager,

Gender Equity,

Technology Start-up,

Women as Managers Scale (WAMS),

Indonesia
*Corresponding Author E-mail: daniya@ipmi.ac.id permits unrestricted use, distribution, and reproduction in any medium, provided the original work is properly cited.

\section{INTRODUCTION}

Gender diversity can sustain the success of an innovative ecosystem like technology companies that are widely known as a start-up. Barker et al. (2014), in the research summary about the impact of gender diversity on technology business performance, tell that gender diversity will 
encourage more innovation. Moreover, gender diversity also improves company financial performance, especially when women hold a significant role in the top management level (Krishnan \& Park, 2005; Hoogendoom, 2013).

Although gender diversity has proven to be one of the key success factors, there is still a gap in the number of female employees in Indonesia technology companies. For instance, according to iPrice (2018), women who hold managerial positions are only $31 \%$ of the total technology companies. The discrepancy becomes more obvious as the job level getting higher. The percentage of female participation in the level of head division is $36 \%$. While both in the level of director and president director only takes to 21\%. Additionally, in the Mapping \& Database Startup, MIKTI Indonesia Digital Creative Industry Society with BEKRAF discovered that the rate of female technology start-up founders is just 8.82\% (MIKTI \& Teknopreneur Indonesia (2018).

There is still confusion why so few women have reached top management positions or become directors in companies. "Think manager, think male" assumptions (Schein, 1973; Schein et al., 1996) are commonly cited as a root cause of the problem. On one side, women are still seen as not having the necessary skills and abilities to carry upper-level management positions (Güney, et al., 2006; Catalyst, 2006). Men, especially male managers have more tendencies to practice gender stereotype in terms of a successful manager (Eriksson et al., 2006). On the other hand, women may also do a stereotype towards themselves (Ashcraft, 2012). If the idea of gender stereotype repeatedly exposed to women, they may unconsciously think they fit into these stereotypes and embrace self-stereotyping behavior and identity. Therefore, the understanding of men and women's attitudes to female managers will be useful to develop gender diversity leadership in tech companies, especially in technology start-up companies in Indonesia.

Overall, in the technology start-up companies, there are two contrary things inside the issue of a female existence as managers. On one side, a startup tech company known as a modern workplace dominated by millennials who openminded and pluralist (Albanese, 2018). While on the opposite, fact and the data show that women's participation in a tech start-up, especially in a managerial position is still small.

To investigate people's attitude towards women as managers in the workplace, a tool called WAMS (Women as Manager Scale) was developed by Tergorg etal. (1977) which measures people's attitude towards female managers' ability, acceptance, physical constraints and leadership skills. In Indonesia, the utilization of WAMS tools is still low. Additionally, the research on attitudes towards female manager in Indonesia tech startup never been done. The current Indonesia studies about attitudes towards female managers are not concentrating on any specific industry (Sany \& Rahardja, 2016; Putra, 2009; Maulana, 2017).

Therefore, this study aims to fill in the above research gaps by investigating whether there are differences in the attitudes between men and women towards female manager using WAMS. To achieve the research objective, this study answers the following research questions.

1. Are there any differences in men's and women's attitudes towards the ability of female managers in technology start-up companies in Jakarta? Why?

2. Are there any differences in men's and women's attitudes towards the acceptance of female managers in technology start-up companies in Jakarta? Why?

3. Are there any differences in men's and women's attitudes towards the physical constraints of female managers in technology start-up companies in Jakarta? Why?

4. Are there any differences in men's and women's attitudes towards the leadership skills of female managers in technology start-up companies in Jakarta? Why?

The following literature review discusses about the ability, acceptance, physical condition and leadership related to WAMS in more detail. 


\section{LITERATURE REVIEW}

\section{WAMS (Women as Manager Scale)}

Terborg etal. (1977) discover WAMS (Women as Manager Scale) as a tool to measure attitudes towards female managers. They were aware that there is differential treatment between men and women in the managerial position. A lot of people have assumptions if women are lack of aggressiveness, ambition, leadership ability, and other required things for being a manager. At that time, although many research has begun to examine the effects of sex-stereotypes on women in business, in actuality, no accurate measure of stereotypes was ever taken.

Existing tools for the assessment of attitudes towards female managers are inadequate. Spence \& Helmreich (1972) developed 55-items of Attitudes towards Women Scale that only consist of a few items which relate to attitudes toward working women. As a result, their measure is too general to be used as an assessment for stereotypes about women in a managerial position. Bass et al. (1971) create another questionnaire that made to measure attitudes towards women managers. However, some items have poor wording. Moreover, all of the questions are leads to unfavorable directions for women managers, against existing rules for attitude scale development (Likert, 1932). Schein (1973) developed a scale that has a function to determine if the middle management position required personal traits with men or women characteristics. The scale will not measure the full range of attitudes towards women as a manager. Therefore, Terborg et al. (1977) develop WAMS as a clear assessment of attitudes towards women managers.

\footnotetext{
Ability

The Cambridge dictionary (n.d) defines ability as a physical or mental power or skill needed to do something, while Oxford dictionary (n.d.) also refers ability as a skill to do something like talent or proficiency in a particular area. According to WAMS, ability relates to the perception of women's ability to succeed as managers (Bowen etal., 2007).
}

Litwin et al. (2019) posits that the components in the ability include some dominant personalities like assertiveness and aggressiveness. A dominance character is frequently seen as a necessary thing that should be possessed by leaders (Kalma et al., 1993). Speed et al. (2017) even show there is a relation between leader assertiveness with subordinates' satisfaction.

However, dominant behaviors can yield to negative results for women. There is a society belief on how men and women should act, like women should be selfless, agreeable, and not demanding. Various studies demonstrate genderlinked personality traits of openness, warmth or extraversion, interpersonal sensitivity, and othercenteredness for women while men are associated with dominance, intellect, and assertive (De Bolle et al., 2015; Weisberg et al., 2011; Chapman et al., 2007). By displaying characteristics that are viewed as a male role, women who perform dominance traits are considered violating the essence of gender role and may get social punishments as a consequence.

In the meta-analysis of 63 studies, Williams \& Tiedens (2016) found that men can behave dominantly, including act assertively, without being seen as less likable. At the same time, if women did not behave assertively, they will also get negative feedback for failing to communicate effectively in a workplace environment. Eventually, that creates a dilemma for women (Speed et al., 2017).

Another component in the ability is the competitiveness of women compared to men. Career interruption becomes one of the issues when discussing women work competitiveness. Women are seen as a small investment in human capital (Barberá et al., 2002; Jacobs, 1999). The research suggests many women, who do not have much time outside working hours to spend in training or coaching, are eliminated from job promotion. Besides, it is common if women put aside their professional career or work part-time to take care of their families. That means they will have fewer years of work experience, which 
slows down their professional growth (Keith \& McWilliams, 1999; Pons Peregort et al., 2013).

\section{Acceptance}

The second variable of WAMS is acceptance, which refers to society's acceptance of women as managers (Bowen et al., 2007). Community acceptance is one of the most crucial issues in the development of female managers. The famous phrase of glass ceiling prevents women and minority groups from reaching higher career ladder and takes credit of neither their abilities nor performance record (Foley et al., 2002; Northouse, 2013). Even the cracks have begun, women who made it still facing hard times when holding a significant leadership position in the office (Bruckmüller \& Branscombe, 2010; Haslam \& Ryan, 2008).

Despite the modernization and changes in gender roles, traditional values and conservative perceptions of gender functions remains strong. Research about gender stereotypes shows people judge women to be less competent and knowledgeable, except in situations that favor female expertise (Carli \& Eagly, 1999) and less qualified as managers compared to men (Schein et al., 1996; Sczesny, 2003). Furthermore, women are expected to only focus on their responsibility towards family and prove their self by taking extra tasks than men in similar positions (BlairLoy, 2001). Gender stereotype becomes a product results from this gender role expectation on women as caregivers (Eagly \& Karau, 2002).

As an outcome, women experienced genderbased differentiation like lower pay and underappreciation of their skills (Mainiero \& Sullivan, 2005). Women believe that they are not involved in significant decision making, and because of their gender, the company did not give the most attractive kinds of work, promotions, or pay increments (Yee et al., 2015). Biernat \& Fuegen (2001) indicate that there is a different standard in the performance evaluation between men and women. Compared to men, the expectation of women performance is smaller. Therefore, the minimum competence standard is set lower for women and higher for men. Besides, males who mostly dominate the management is likely to form the company culture and develop performance assessment systems that may be favored by men, but not women (Festing et al., 2015).

Society or community avoidance in practicing gender stereotype is necessary. Eventually, gender stereotypes cause damage to the company. When women believe and accept the existence of stereotypes, they will stress because they traditionally considered less competent than men. That can affect women's performance since the stereotype is upheld. Besides, a woman who is interested in pursuing jobs in managerial level might lose interest after experiencing or seeing negative attitudes towards a woman in such positions (Gino et al., 2015). Companies that discriminate women who ask promotion into the same position as men may lose valuable human resources when women choose to select another path for enhanced professional responsibilities than the only one their company seems to be able to offer (Mainiero \& Sullivan, 2005).

Research by O'Neil \& Bilimoria (2005) even strongly suggests that an organization must support career development program for women, like management trainee to retain or having talented professional women. The company or organization must ensure women receive ongoing mentoring, coaching, and managers who support their career development. Additionally, the company also needs to create fair policies that will give impact to the quality of work environments for all workers, including women.

\section{Physical Constraint}

The physical constraint is the third principal measurement in WAMS. Bowen et al. (2007) defined it as perceptions of women's reproductive function as an obstacle to their success for being managers. The physical constraint components cover issues such as menstruation and pregnancy that should not make women less desirable than men as employees. Sacrifices of women towards their femininity also being another topic 
discussed in this session.

There is some negative stigma that associates to women particular physical condition, like pregnancy. Pregnant women are identical as more emotional, illogical, and less dedicated to their jobs (Halpert et al., 1993), and less competent compared to other employees (Butensky, 1984). Additionally, co-workers feel that pregnant women are not capable of doing works in the required work hours. Therefore, they create more work for them (Gueutal \& Taylor, 1991). Another assumption is the pregnant worker will not return to work after childbirth (Halpert \& Burg, 1997; Major, 2004).

A similar phenomenon happens in the relation between women's menstruation cycle and working ability. Women might experience premenstrual syndrome or known as PMS (Johnson, 1987; Steiner, 1997). They will face some somatic and affective symptoms behavior, for instance, low energy, irritability, depressed mood, and anxiety (Dickerson, 2003). Hence, people see these symptoms can give a negative impact on job performance.

Regardless of the people stereotype, menstruation is not influencing a woman's cognitive performance. Leeners et al. (2017) stated that levels of estrogen, progesterone, and testosterone in a woman's body have no impact on her working memory, cognitive bias or capability to concentrate on two things at once. Although a larger sample and further studies need to be conducted to understand the whole impact of menstruation on the brain, women's cognitive performance is in general not disrupted by hormonal changes that occur along with the menstrual cycle.

Besides pregnancy and menstruation, women femininity traits also represent another measurement in the dimension of physical constraint. The question from WAMS regarding femininity states that it is necessary for women to sacrifice their femininity as a manager or leader. The issue of femininity indeed crucial since there is a perspective on a strong relationship between manager positions with masculinity (Schein, 1973).

\section{Leadership}

Leadership has many definitions. Zaccaro \& Banks (2001) describe leadership as situations when leader setting and communicate a direction to their subordinates. Day et al. (2014) explain it as a more complex subject since it involves interactions between a leader, follower, and situation at various levels of the organization. According to Litwin et al. (2019), leadership in WAMS is a perception regarding women who hold leadership position like a manager.

Some previous research has shown differences between women and men leadership style, which sometimes interpreted differently and lead stereotype towards female leaders (Javidan et al., 2016; Eagly \& Johnson, 1990). Women are seen as more into participative or democratic style, and likely to express person-oriented leadership approaches (Duff, 2013). Therefore they viewed as s ervant style leaders who prioritize on the followers and their needs. Conversely, men have an image as authentic leaders that more taskoriented who own characters of individualist and genuine (Ibarra, 2015).

The phenomenon of grouping a leadership style on gender-based is harming women leaders who may have authentic features or characteristics. Moreover, men's specialization that relatively seen as strictly task-oriented is one passkey to their rise as group leaders (Eagly \& Karau, 1991), consequently assuring that men would be perceived as a better "fit" than women in the role of leadership.

As a more high-status individual, men are expected to perform well. Because of that, they tend to own more opportunities for contributing to their organizations and obtain a positive evaluation of their contributions (Berger et al., 1980; Powell, 2014). In result, the opportunities for promotion to leadership levels are increasing as well (Carli \& Eagly, 1999). 


\section{RESEARCH METHODS}

\section{Research Approach}

The study adopts the mixed method with a quantitative phase followed by the qualitative. Mixed method was used because it presents both confirmatory and exploratory inquiries that will make the data more meaningful. The quantitative analysis will provide a general understanding of gender-based perspective towards female managers in technology start-up companies in Jakarta, while qualitative data refined and explicated statistical results by explaining and exploring the reasons behind the attitude.

\section{Sampling Method \& Sampling Size}

The data of total people working in technology startup companies in Indonesia is not available. Since the population is unknown, to determine the number of quantitative sampling, every item used in the scale will be multiplied by five (Hair et al., 2011). Therefore, 12 items multiplied by five is 60 . As a result, total respondents needed for quantitative method is 60 males and 60 females. The sample for qualitative analysis is different compared to quantitative analysis. There is no exact number about how small or big the sample in qualitative research. The sampling must stop when adding more participants does not gain any additional perspectives or information (Saunders et al., 2012)

\section{Research Target}

In quantitative and qualitative respondents have similarities and differences in terms of criteria. The same thing is there no geographical difference between the respondents of quantitative and qualitative methods. A work location of the respondents must be in Jakarta. Another point is quantitative and qualitative respondents also need to work in technology start-up companies in Jakarta. While the difference is respondents of qualitative approach must have at least two years' experience in the technology startup industry. According to Ryan \& Bernard (2006), respondents experience and confidence will impact the research result. Therefore, it is better if the interviewee has experienced so that the answers are more comprehensive.

\section{Research Design}

This research is using WAMS as the principal instruments. All of the research indicators is refers to Litwin et al. (2019). Their research was already done the confirmatory factor analysis to know the indicators for each dimension in WAMS. Hence, all of the quantitative and qualitative questionnaires will be made based on the indicators. The following Table shows the operational definitions and indicators used in this study.

Table 1. Women as Managers Scale Components

\begin{tabular}{|c|c|c|}
\hline \multicolumn{3}{|c|}{ WAMS (Women as Manager Scale) } \\
\hline Components & Definition & Indicators \\
\hline Ability & $\begin{array}{l}\text { Perception of women's ability to succeed as } \\
\text { managers (Bowen et al., 2007) }\end{array}$ & $\begin{array}{l}\text { 1. Women's ability to be assertive as manager } \\
\text { 2. Women's ability to be aggressive as manager } \\
\text { 3. Women competitiveness to success in the business world }\end{array}$ \\
\hline Acceptance & $\begin{array}{l}\text { Society's acceptance of women as managers } \\
\text { (Bowen et al., 2007) }\end{array}$ & $\begin{array}{l}\text { 1. Business world acceptance towards women in significant } \\
\text { managerial position } \\
\text { 2. Women and men equal opportunity for participate in } \\
\text { management trainee } \\
\text { 3. Recognition to working results of female managers } \\
\text { 4. Opinion to women who compete for executive or senior } \\
\text { management positions }\end{array}$ \\
\hline $\begin{array}{l}\text { Physical } \\
\text { Constraint }\end{array}$ & $\begin{array}{l}\text { Perceptions of women's reproductive function } \\
\text { as an obstacle to their success for being } \\
\text { managers (Bowen et al., 2007) }\end{array}$ & $\begin{array}{l}\text { 1. Effect on women's menstruation towards company hiring } \\
\text { desirability } \\
\text { 2. Effect on women pregnancy towards company hiring } \\
\text { desirability } \\
\text { 3. Women femininity sacrifices to be successful executive }\end{array}$ \\
\hline Leadership & $\begin{array}{l}\text { Leadership in WAMS is a perception regarding } \\
\text { women who hold leadership position like } \\
\text { a manager (Litwin et al., 2019) }\end{array}$ & $\begin{array}{l}\text { 1. Contributions of women manager toward the organization } \\
\text { 2. Acceptance if women take leadership roles as often as men }\end{array}$ \\
\hline
\end{tabular}




\section{Data Collection}

A survey was conducted to gather the quantitative data in this study. The questionnaire is applied as the main instrument in this method. Referring to all previous research, the type of question on the WAMS survey is using multiple-choice questions. Five points of Likert scale become the tools for the multiple-choice answer, which ranges from strongly disagree as scale number one and strongly agree the scale number five. For collecting qualitative data, the method will be face to face interview. A semi-structured interview is conducted to make discovery or elaboration of information more flexible. There will be several key questions that refer to a quantitative questionnaire to define the areas to be explored.

\section{Data Analysis}

There are two software used in the data analysis. The data analysis of the survey questionnaire or quantitative methodology is using IBM SPSS Statistics 22. While the interview result is summarized manually by making a table in Microsoft Word.

\section{RESULT AND DISCUSSION}

\section{Demography of Quantitative Respondents}

The socio - demographic of quantitative respondents reveal several information. First, the start-up technology industry in Jakarta majority consists of young people since most of the respondents in the age of 18-27 years old. Second, a technology start-up companies in Jakarta are mostly located in South and West Jakarta. Third, more than $90 \%$ of respondents have a bachelor's degree as the current education. Fourth, the job status of most respondents is fulltime workers. Fifth, the number of respondents in the entry-level is dominating compared to the other job level. Sixth, the respondents in this research mostly spend less than one year until one year in the technology start-up industry although the number of respondents that work for two until three years in the industry is also large.

\begin{tabular}{|c|c|c|}
\hline Age & Female & Male \\
\hline $18-27$ & 51 & 49 \\
\hline $28-37$ & 8 & 11 \\
\hline $38-47$ & 1 & 0 \\
\hline \multicolumn{3}{|l|}{ Office Location } \\
\hline North Jakarta & 2 & 4 \\
\hline South Jakarta & 31 & 34 \\
\hline Central Jakarta & 5 & 8 \\
\hline West Jakarta & 22 & 14 \\
\hline East Jakarta & 0 & 0 \\
\hline \multicolumn{3}{|l|}{ Education } \\
\hline High School & 0 & 0 \\
\hline Vocational & 6 & 4 \\
\hline Bachelor & 50 & 49 \\
\hline Masters & 4 & 7 \\
\hline Doctoral & 0 & 0 \\
\hline \multicolumn{3}{|l|}{ Job Status } \\
\hline Freelance & 2 & 4 \\
\hline Full-time & 53 & 56 \\
\hline Part-time & 5 & 0 \\
\hline \multicolumn{3}{|l|}{ Job Level } \\
\hline Entry Level & 37 & 30 \\
\hline First-line Management & 14 & 18 \\
\hline Middle Management & 8 & 8 \\
\hline Top Management & 1 & 4 \\
\hline \multicolumn{3}{|c|}{ Years in Technology Start-up Industry } \\
\hline$<1-1$ year & 31 & 27 \\
\hline $2-3$ years & 21 & 24 \\
\hline $4-5$ years & 8 & 9 \\
\hline
\end{tabular}

\section{Demography of Quantitative Respondents}

Three of the respondents are men, and the other three are women. All of them work in different types of companies, from financial technology to shipping or logistics service providers. The average experience in the tech start-up industry also varies. There is one person who has only been in the tech start-up industry for two years. His position is not at the managerial level, only a regular staff. However, the majority or three respondents have experienced for three years. Their current job is as a manager in a division. Whereas, the other two respondents who have experience of four to five years are co-founders of their own company. 
Table 3. Socio-demographic characteristics of qualitative participants

\begin{tabular}{|c|c|c|c|c|}
\hline No & Gender & Type of Company & $\begin{array}{c}\text { Years in Technology Start-up } \\
\text { Companies }\end{array}$ & Current Position \\
\hline 1 & Female & Financial Technology & 3 years & Business Technology Manager \\
\hline 2 & Male & Accelerator/ Incubator & 4 years & Co-Founder \\
\hline 3 & Male & Marketplace & 3 years & Head of Engineer \\
\hline 4 & Female & Retail & 3 years & Project Manager \\
\hline 5 & Male & Travel Service Provider & 2 years & iOS Engineer \\
\hline 6 & Female & Logistics & 5 years & Co-Founder \\
\hline
\end{tabular}

\section{Research Result}

The first analysis on the research data is reliability analysis. After running the test in SPSS, the value of Cronbach's alpha is 0.692 as shown in Table 4. Referring to Sekaran \& Bougie (2016), the number of 0.6 is still acceptable.

Table 4. Reliability Analysis

\begin{tabular}{|c|c|}
\hline Cronbach's Alpha & N of Items \\
\hline 0.692 & 4 \\
\hline
\end{tabular}

In the normality statistical examination, all variables in WAMS are not having normally distributed data. The $\mathrm{p}$ value of acceptance and leadership are zero for both male and female. While for the ability, for female respondents, the value is 0.02 in the Kolmogorov-Smirnov test and 0.04 the Shapiro-Wilk test. For male respondents, the sig value is zero in the Kolmogorov-Smirnov test, but the sig value is 0.01 in the Shapiro-Wilk test. The physical constraint also does not fully show zero results. Male gender still has a value of 0.03 as the $\mathrm{p}$-value or sig in both of the KolmogorovSmirnov test and the Shapiro-Wilk test.

According to Sekaran \& Bougie (2016), for not normally distributed data, the non-parametric test must be conducted. The non-parametric test has aimed to determine whether there is a difference in the average group of the sample.

Table 6. Ranks of Non-Parametric Test

\begin{tabular}{ccccc}
\hline \multirow{2}{*}{ Ability } & Gender & N & $\begin{array}{c}\text { Mean } \\
\text { Rank }\end{array}$ & $\begin{array}{c}\text { Sum of } \\
\text { Ranks }\end{array}$ \\
\hline \multirow{2}{*}{ Acceptance } & Female & 60 & 73.71 & 4422.50 \\
\cline { 2 - 5 } & Male & 60 & 47.29 & 2837.50 \\
\cline { 2 - 5 } & Female & 60 & 69.31 & 4158.50 \\
\hline \multirow{2}{*}{ Physical Constraint } & Male & 60 & 51.69 & 3101.50 \\
\hline \multirow{2}{*}{ Leadership } & Female & 60 & 73.21 & 4392.50 \\
\cline { 2 - 5 } & Male & 60 & 47.79 & 2867.50 \\
\cline { 2 - 5 } & Female & 60 & 66.79 & 4007.50 \\
\hline
\end{tabular}

The ranks table above is showing that there is a difference between women and men attitudes towards female managers. Women attitudes towards female managers in all aspect of WAMS is more positive compare men attitudes. The most noticeable difference is in terms of ability and physical constraint.

Furthermore, this study also using Mann Whitney $\mathrm{U}$ test to know the significance of two means for both genders.

Table 5. Normality Test

\begin{tabular}{|c|c|c|c|c|c|c|c|}
\hline & \multirow[b]{2}{*}{ Gender } & \multicolumn{3}{|c|}{ Kolmogorov-Smirnov } & \multicolumn{3}{|c|}{ Shapiro-Wilk } \\
\hline & & Statistic & df & Sig. & Statistic & df & Sig. \\
\hline \multirow{2}{*}{ Ability } & Female & 0.152 & 60 & 0.02 & 0.152 & 60 & 0.04 \\
\hline & Male & 0.176 & 60 & 0.00 & 0.176 & 60 & 0.01 \\
\hline \multirow{2}{*}{ Acceptance } & Female & 0.301 & 60 & 0.00 & 0.725 & 60 & 0.00 \\
\hline & Male & 0.175 & 60 & 0.00 & 0.892 & 60 & 0.00 \\
\hline \multirow{2}{*}{ Physical Constraint } & Female & 0.216 & 60 & 0.00 & 0.873 & 60 & 0.00 \\
\hline & Male & 0.121 & 60 & 0.03 & 0.957 & 60 & 0.03 \\
\hline \multirow{2}{*}{ Leadership } & Female & 0.408 & 60 & 0.00 & 0.648 & 60 & 0.00 \\
\hline & Male & 0.284 & 60 & 0.00 & 0.778 & 60 & 0.00 \\
\hline
\end{tabular}


Table 7. Test Statistics Non Parametric

\begin{tabular}{ccccc}
\hline & Ability & Acceptance & $\begin{array}{c}\text { Physical } \\
\text { Constraint }\end{array}$ & Leadership \\
\hline $\begin{array}{c}\text { Mann- } \\
\text { Whitney U }\end{array}$ & 1007.500 & 1271.500 & 1037.500 & 1422.500 \\
\hline Wilcoxon W & 2837.50 & 3101.500 & 2867.500 & 3252.500 \\
\hline Z & -4.266 & -2.894 & -4.051 & -2.228 \\
\hline $\begin{array}{c}\text { Asymp. Sig } \\
\text { (2-tailed) }\end{array}$ & .000 & .004 & .000 & .026 \\
\hline
\end{tabular}

From the result of non-parametric tests, it can be concluded that the difference of attitudes towards female manager in Indonesia technology startup companies between women and men is significant. The way to find out whether the difference is significant is if the value in the column of sig is less than 0.05. Since all aspects or variables in WAMS is having a significance value below 0.05 , then the women and men differences are significant.

\section{Discussion}

Differences in men's and women's attitudes towards the ability of female managers in technology start-up companies in Jakarta. Women's attitudes towards ability of female as managers are more positive than men in technology start-up companies. As the first measurement in WAMS, ability shows mean ranks of women respondents are 73.71, while men ranks are only 47.29. The main reason for that because of the last question that state women are more competitive than men for success in the business world. The number of male respondents said they disagree with the statement is way higher compared to the female respondents who disagree. Compared to women, men are indeed the parties discredited by that statement.

The disagreement regarding the statement was confirmed during the interview session. The male interviewees feel that both women and men are equally competitive. Male respondents in qualitative approach stated that women were able to compete with men because they were very detailed and precise in doing their job. Male interviewee even said they have more respect for women that work in the IT department. They were aware that only a few women who choose a career path in the tech industry and survive in it.

The issue of women's ability to be managers is indeed an interesting discussion when it compared from both women and men perspective. Both genders recognize that women and men have their respective strength or advantages as managers. Men are better at conceptual, technical, and strategic matters. They were also very good at utilizing facts and data. When women are more detailed and like to make a personal touch, they care more about their team members. However, male interviewees more explained a bit on women's weaknesses while female interviewees don't do the same thing.

"Men are quicker to blend in with the new teams or new people, whereas women are often rather shy when they meet new people." (Male Respondent, 2019)

Moreover, another thing about abilities that are equally agreed by male and female interviewees is regarding women's assertiveness. Both agree that women are capable and should be assertive. Assertiveness traits, like talking straightforward or sometimes being aggressive in a negotiation is necessary. Especially in a start-up environment, because things are moves fast and growth is a priority. Assertiveness traits will prevent misleading communication. Thus, it is a positive thing if women being assertive.

\section{Differences in men's and women's attitudes towards the acceptance of female managers in technology start-up companies in Jakarta. In terms of acceptance, although female respondents showed a more positive attitude than male respondents, the average difference between male and female respondents in the questionnaire of the quantitative method is not prominent. The distinction between the average male and female is 12.58. The explanation of why the differences are insignificant will emerge from the interview sessions. Both of the genders show their acceptance reaction to the female manager in detail.}


The noticeable distinction is in the issue on why society acceptance for women to be a manager is important. In the I nterview sessions, female interviewees can give a more detailed explanation regarding this issue. First is because naturally, women have several traits that a leader musthave. For instance, women have nurturing characters that make them have high empathy and happy to see their team develop. Secondly, the existence of women as a leader is essential because a great working environment is the one that has diversity inside it, including gender diversity. Heterogeneity is a source of many different ideas because there will be more perspectives. While the men respondents only said that the presence of women as a leader is essential because women can check and recheck things better than men.

Next section in the topic of acceptance towards female manager talks about the equal opportunity for men and women to participate in a career development program like management training. Female interviewees said that it was more to fairness because women can be as good as men. Men respondents said a similar answer by telling that the company might lose the opportunity for having a better and bigger talent pool if they discriminate against women.

The third question regarding acceptance discusses whether there is a difference between the work result of men and women managers. Female and male interviewee saying that there are no quality differences between men and women. It's just the method that they use is different. Women are more detailed but lack of conceptual. While men are usually good at conceptual, but usually not as neat as women can be. Moreover, ordinarily, men are fast decision-maker. On the other hand, women are more considerate since they are a good planner.

"Women are neater, especially in administrative matters such as making proposals or presenting presentations." (Female Respondent, 2019)

The closing question for the acceptance towards female manager is whether it is acceptable if women want to compete with men for the executive or leader position. Both men and women agree that it is acceptable. But again, the female interviewee response is more detailed compared to the male respondents. Female respondents told it is acceptable, especially in the start-up industry where most of the people in that industry are modern and forwardthinking. However, still, there are some people that reluctant towards women who become leaders or managers. Therefore, women must fight and prove that they can compete. Male respondents confirm the response of female respondents by saying women can do the work and manage their team well.

\section{Differences in men's and women's attitudes towards physical constraints of female managers in technology start-up companies in} Jakarta. Women's attitude towards physical constraints of female managers are more positive than men attitude. For physical constraint, the result of quantitative questionnaire shows a quite big difference with 73.21 as mean ranks of women respondents, and 47.79 as means of the men respondents. Further reason on why the differences exist is known from the interview sessions.

Interviews with respondents indicate that the difference lies in the opinion regarding emotional stability during menstruation and maternity leave. Male interviewees believe that women are more sensitive during menstruation due to hormonal changes. On the other hand, female interviewees feel that emotional instability during menstruation is most likely happen because of personal suggestion. Regarding maternity leave, none of the female respondents thought that maternity leave would affect work performance. However, male respondents assume that maternity leave will give impact to the team work performance if a person that takes the dispensation is a leader or manager. Maternity leave is usually happening for three until four months. Over a long time, the team's performance may decrease due to the absence of their leader. 
Despite differences in opinion between women and men on menstruation and pregnancy, they both agree on one point regarding that issue. Female and male interviewees agreed that it was not a big deal if women were absent for one to two days due to menstruation. In a start-up, the terms of working from home are something usual. So it does not matter as long as the work is done or finished. Additionally, the female respondents or interviewees have an opinion that women should not misuse the menstrual leave. Some people think that women are weak and need to be treated differently because of pain during menstruation. Hence, women must use the menstrual leave wisely, only when the pain is unbearable for them to go to the office.

Besides the problem of menstrual leave, the male and female interviewee has a no different opinion regarding women leaders that must sacrifice their femininity traits. Every leader has their approach and method. The femininity traits are the one that makes female leaders is valuable and unique. A good leader can understand when is the right time to be empathy or show some tenderness, and when to act firm. Even if a woman manager must behave firmly, it doesn't mean they are mean or rude.

"At the beginning, a leader must show empathy first. After that, if a leader or manager has to be firm, then they can act firmly to their team members. Being assertive does not mean being cruel." (Male Respondent, 2019)

Differences in men's and women's attitudes towards leadership skills of female managers in technology start-up companies in Jakarta. Leadership is the WAMS dimension with the smallest differences between men and women. The mean or average value of men is 55.21 and women is 66.79 . The difference between both of the gender only 12.58 .

The small gap between men and women opinion also reflected in the interview sessions. First question asks whether there are contribution differences between men and women for achieving company's overall goals. Then male and female respondents agree that there are no differences, again, the difference is only in the working method, not in the working result.

While for the last question, the answer is similar with a slight difference. Female interviewees told it is acceptable if women want to step as a leader. However, not every woman wants to take such positions. For a married woman with a child, they think about how to manage the time between family and personal life with work matters. While for a single woman, they sometimes feel fear to take bigger responsibility.

"The small number of women leaders does not only come from people's impressions towards women that being a leader. It also comes from the women themselves who refuse to take that role." (Female Respondent, 2019)

Male interviewees also said it is acceptable if women want to take a leadership role. However, they have a different thought on why the number of women managers is less than men manager. Men think that leader emerges naturally from a group, someone will be chosen if he or she is the one with the highest leadership quality in that group. Maybe men were often preferred as a leader because there are many times when women decide to keep a low profile because they are shy or fear to compete with men. In the end that lower the score of leadership quality.

\section{CONCLUSION}

This study answers the research questions related to differences in male's and female's attitudes towards female managers' ability, acceptance, physical constraints and leadership. Compared to this study provides a deeper analysis on the application of WAMS as it applies both quantitative and qualitative approaches. The qualitative analysis gives detailed opinion from both men and women side. As a result, the study not only tells that there are different perspectives between men and women but also tries to understand why these differences exist. 
Moreover, this research contributes to the human resources sector of Indonesia technology startup companies, specifically in terms of gender diversity management. Previous research on this topic and in this industry has never been done in Indonesia. The study outcome shows women attitudes towards female managers are more positive compared to the men's attitudes.

This research has some limitations. First, it is conducted in greater area of Jakarta with limited samples and only focus on technology start-up companies. Future researchers can do two things for making the study more comprehensive. First, the researcher can study the overall start-up companies in Indonesia, not limited to a particular area in Indonesia. Second, the researcher needs to study specifically regarding the factors of why only a few women that being a leader in techstartup companies, especially in the IT division. Differences of opinion between women and men towards female managers might be one of the reasons why the numbers of female managers in the tech start-up industry are small. However, there are still other causes or possibility that needs to be explored.

\section{REFERENCES}

Albanese, J. (2018, November 26). Millennials: architects of the modern workplace. Retrieved from Inc. Southeast Asia: https://www.inc.com/jason-albanese/millennials-architects-of-modernworkplace.html.

Ashcraft, C., Eger, E., \& Friend, M. (2012). Girls in IT: the facts. Colorado: National Center for Women \& Information Technology.

Barberá H, E., \& Ramos L, A. (2004). Liderazgo y discriminación de género. Revista de Psicología General y Aplicada, 57(2), 147-160.

Barker, L., Manca, C., \& Ashcraft, C. (2014). What is the impact of gender diversity on technology business performance. Colorado: National Center for Women \& Information Technology.

Bass, B. M., J. Krusell, R. A. Alexander (1971). Male managers' attitudes toward working women. American Behavioral Scientist, 15, 221-236.

Berger, J., Rosenholtz, S. J., \& Zelditch, M. (1980). Status organizing processes. Annual Review of Sociology, 6, 479-508.

Biernat, M., \& Fuegen, K. (2001). Shifting standards and the evaluation of competence: Complexity in gender-based judgment and decision making. Journal of Social Issues, 57(4), 707-724.

Blair-Loy, M. (2001). Cultural constructions of family schemas: The case of women finance executives. Gender \& Society, 15, 687-709.

Bowen, C.-C., Wu, Y., Hwang, C.-e., \& Scherer, R. F. (2007). Holding up half of the sky? Attitudes toward women as managers in the People's Republic of China. The International Journal of Human Resource Management, 18(2), 268-283.

Bruckmüller, S., and Branscombe, N. R. (2010). The glass cliff: When and why women are selected as leaders in crisis contexts. British Journal of Social Psychology, 49, 433-451.

Butensky M. (1984). Devaluation of the competence of pregnant women: Does the spread phenomenon that operates with disabilities also occur with pregnancy? Dissertation Abstracts International, 45, 718 B.

Cambridge Dictionary (n.d.). Retrieved June 17, 2019 from http://www.dictionary.cambridge.org/ability.

Chapman, B. P., Duberstein, P. R., Sörensen, S., \& Lyness, J. M. (2007). Gender differences in Five Factor Model personality traits in an elderly cohort. Personality and Individual Differences, 43(6), 15941603. 
Carli, L. L., \& Eagly, A. H. (1999). Gender effects on social influences and emergent leadership. In G. N. Powell (Ed.), Handbook of gender and work (pp. 67-222). Thousand Oaks, CA: Sage.

Catalyst. (2006). Different cultures, similar perceptions: stereotyping of western European. New York, Catalyst and Institute for Management Development.

Day, D. V., Fleenor, J. W., Atwater, L. E., Sturm, R. E., \& McKee, R. A. (2014). Advances in leader and leadership development: A review of 25 years of research and theory. The Leadership Quarterly, 25, 63-82.

De Bolle, M., De Fruyt, F., McCrae, R. R., Löckenhoff, C. E., Costa Jr, P. T., Aguilar-Vafaie, M. E., \& Terracciano, A. (2015). The emergence of sex differences in personality traits in early adolescence: A crosssectional, cross-cultural study. Journal of Personality and Social Psychology, 108(1), 171 - 185.

Dickerson, L.M., Maryecd, P.S. and Hunter, M.H. 2003. Premenstrual syndrome. American Family Physician, 67(8):1743-1752.

Duff, A.J. (2013). Performance management coaching: Servant leadership and gender implications. Leadership and Organization Development Journal, 34(3), 204-221.

Festing, M., Knappert, L., \& Kornau, A. (2015). Gender-specific preferences in global performance management: An empirical study of male and female managers in a multinational context. Human Resource Management, 54(1), 55-79.

Foley, S., Kidder, D. L., \& Powell, G. N. (2002). The perceived glass ceiling and justice perceptions: An investigation of Hispanic law associates. Journal of Management, 28(4), 471-496.

Eagly, A. H., \& Johnson, B. T. (1990). Gender and Leadership Style: A Meta-Analysis. Psychological Bulletin, $108(2), 233-256$.

Eagly, A. H., \& Karau, S. J. (1991). Gender and the Emergence of Leaders: A Meta-Analysis.Journal of Personality and Social Psychology, 60(5), 685-710.

Eagly, A. H., and Karau, S. J. (2002). Role congruity theory of prejudice toward female leaders. Psychol. Rev. 109, 573-598.

Eriksson, Marit \& Rasmussen, Finn \& Tynelius, Per. (2006). Genetic Factors in Physical Activity and the Equal Environment Assumption - the Swedish Young Male Twins Study. Behavior genetics. 36. 23847.

Gino, F., Brooks, A. W., \& Wilmuth, C. A. (2015). Compared to men, women view professional advancement as equally attainable, but less desirable. Proceedings of the National Academy of Sciences 112(40), 12354-12359.

Gueutal, H. G., \& Taylor, E. M. (1991). Employee pregnancy: The impact on organizations, pregnant employees and co-workers. Journal of Business and Psychology, 5(4), 459-476.

Güney, S., Gohar, R., Akıncı, S. K., \& Mutlu, M. (2006). Attitudes towards women managers in Turkey and Pakistan. Journal of International Women's Studies, 8(1), 194-211.

Hair, J. F., Ringle, C. M., \& Sarstedt, M. (2011). PLS-SEM: indeed a silver bullet. Journal of Marketing Theory and Practice, 19(2), 139-151.

Halpert, J. A., Wilson, M. L., \& Hickman, J. L. (1993). Pregnancy as a source of bias in performance appraisals. Journal of Organizational Behavior, 14(7), 649-663.

Haslam, S. A., and Ryan, M. K. (2008). The road to the glass cliff: Differences in the perceived suitability of men and women for leadership positions in succeeding and failing organizations. The Leadership Quarterly, 19, 530-546.

Hoogendoorn, Sander \& Oosterbeek, Hessel \& Praag, Mirjam. (2013). The Impact of Gender Diversity on the Performance of Business Teams: Evidence from a Field Experiment. Management Science. 59. 1514-1528.

Ibarra, H. (2015). The authenticity paradox. Harvard Business Review, 93, 53-59.

iPrice. (2018). Kesetaraan Gender di Industri E-commerce Indonesia. Retrieved from iPrice Indonesia: https://iprice.co.id/trend/insights/kesetaraan-gender-tenaga-kerja-indonesia/. 
Jacobs, S. (1999). Trends in women's career patterns and in gender occupational mobility in Britain. Gender, work and organization, 6(1), 32-46.

Javidan, M., Bullough, A., \& Dibble, R. (2015). Mind the gap: gender differences in global leadership selfefficacies. The Academy of Management Executive, 30(1), 59-73.

Johnson, S. R. (1987). The epidemiology and social impact of premenstrual symptoms. Clinical Obstetrics and Gynecology, 30(2), 367-376.

Kalma, A. P., Visser, L., \& Peeters, A. (1993). Sociable and aggressive dominance: Personality differences in leadership style? The Leadership Quarterly, 4(1), 45-64.

Keith, K., \& McWilliams, A. (1999). The Returns to Mobility and Job Search by Gender. ILR Review, 52(3), 460-477.

Krishnan, H. A., \& Park, D. (2005). A few good women-on top management teams. Journal of Business Research, 58(12),1712-1720.

Leeners, B., Kruger, T., Geraedts, K., Tronci, E., Mancini, T., Ille, F., Egli, M., Röblitz, S., Saleh, L., Spanaus, K., Schippert, C., Zhang, Y., Hengartner, M.P. (2017). Lack of association between female hormone levels and visuospatial working memory, divided attention, and cognitive bias across two consecutive menstrual cycle. Frontiers in Behavioral Neuroscience, $11(120)$.

Likert, R. (1932). A technique for the measurement of attitudes. Archives of Psychology, 140,44-53.

Litwin, A., Ngan, H. F., \& Roland, A. (2019). Attitudes towards female managers in Austrian and Macau tourism industry. Journal of Hospitality and Tourism Management39, 1-8.

Mainiero, L.A. \& Sullivan, S.E. 2005. "Kaleidoscope Careers: An Alternate Explanation for the Opt-Out Revolution". Academy of Management Executive, 19(1), 106-123.

Major. V.S. (2004). Pregnancy in the workplace: Stigmatization and work identity management among pregnant employees.

Maulana, S. I. (2017). Persepsi Masyarakat Terhadap Kepemimpinan Perempuan di Kota Banda Aceh. Online Theses \& Dissertation Universitas Syiah Kuala. Retrieved from: https://etd.unsyiah.ac.id/index.php?p=show_detail\&id=30079

MIKTI \& Teknopreneur Indonesia. (2018). Mapping \& Database Startup Indonesia 2018. Jakarta: MIKTI. Northouse, P. (2013). Leadership: Theory and practice (6thed.). Thousand Oaks, CA: Sage.

Oxford Dictionary (n.d). Retrieved June 17, 2019 from https://www.lexico.com/en/definition/ability.

O'Neil, D., \& Bilimoria, D. (2005). Women's career development phases: Idealism, endurance, and reinvention. Career Development International 10,168-169.

Pons P, O., Calvet M.D., Tura S, M., \& Muñoz I, C. (2013). Análisis de la Igualdad de Oportunidades de Género en la Ciencia y la Tecnología: Las carreras profesionales de las mujeres científicas y tecnólogas. Intangible Capital, 9(1), 65-90.

Powell, G. N. (2014). Sex, Gender, and Leadership. In S. Kumra, R. Simpson \& R. J. Burke (Eds.), The Oxford Handbook of Gender in Organizations (pp. 249-268). New York, NY: Oxford University Press.

Putra, A. C. (2009). Persepsi tentang kepemimpinan perempuan di kalangan pelajar pria SMK Negeri 6 Surakarta. Universitas Sebelas Maret Institutional Repository. Retrieved from: https://eprints.uns.ac.id/5823/1/110201002201008021.pdf.

Ryan, G.W \& Bernard, H.W. Data Management and Analysis Methods In: N. K. Denzin and Y. S. Lincoln, Eds. Handbook of Qualitative Research, 2nd Edition. Sage Publications, Thousand Oaks, pp. 769-802.

Sany, N., \& Rahardja, E. (2016). Membedah stereotip gender: persepsi karyawan terhadap seorang general manager perempuan. Diponegoro Journal of Management, 5(3), 1-9.

Saunders, M., Lewis, P. \& Thornhill, A. (2012) Research Methods for Business Students. Harlow: Pearson Education Ltd.

Schein, V. E. (1973). The relationship between sex role stereotypes and requisite management chara cteristics. Journal of Applied Psychology 57(2), 95-100. 
Schein, V. E., Mueller, R., Lituchy, T., \& Liu, J. (1996). Think Manager -- Think Male: A Global Phenomenon? Journal of Organizational Behavior 17(1),33-41.

Sczesny, S. (2003). A closer look beneath the surface: various facets of the think-manager-think-male stereotype. Sex Roles, 49, 353-363.

Speed, B. C., Goldstein, B. L., \& Goldfried, M. R. (2017). Assertiveness training: A forgotten evidence-based treatment. Clinical Psychology: Science and Practice, 25(1).

Spence, J. R., and R. Helmreich (1972). The attitudes toward women Scale: an objective instrument to measure attitudes toward the rights and roles of women in contemporary society. JSAS Catalog of Selected Documents in Psychology 2, 66-67.

Steiner, M. (1997). Premenstrual Syndromes. Annual Review of Medicine, 447-455.

Terborg, J. R., Peters, L. H., Ilgen, D. R., \& Smith, F. (1977). Organizational and personal correlates of attitudes toward women as managers. Academy of Management Journal, 20(1), 89-100.

Weisberg, Y. J., DeYoung, C. G., \& Hirsh, J. B. (2011). Gender differences in personality across the ten aspects of the big five. Frontiers in Psychology, 2 (178).

Williams, M. J., \& Tiedens, L. Z. (2016). The subtle suspension of backlash: A meta-analysis of penalties for women's implicit and explicit dominance behavior. Psychological Bulletin, 142(2), 165-197.

Yee, L., Krivkovich, A., Kutcher, E., Epstein, B., Thomas, R., Finch, A., Konar, E. (2015). Women in the workplace 2015. McKinsey \& Company. Retrieved from: https://womenintheworkplace.com/2015.

Zaccaro, S. J., \& Banks, D. J. (2001). Leadership, vision, and organizational effectiveness. In S. J. Zaccaro \& R. J. Klimoski (Eds.), The Jossey-Bass business \& management series. The nature of organizational leadership: Understanding the performance imperatives confronting today's leaders, 181-21. 